\title{
Disain dan Uji Kinerja Pendingin Evaporatif Tipe Aliran Searah Menggunakan CFD (Computational Fluid Dynamics)
}

\section{Design and Performance of Direct Flow Type Evaporative Cooler Using CFD (Computational Fluid Dynamics)}

\author{
Hikmah Yuliasari ${ }^{1}$, Kavadya Syska ${ }^{1,2} \otimes$, Ropiudin $^{2}$ \\ ${ }^{1}$ Program Studi Teknologi Pangan, Fakultas Sains dan Teknologi, Universitas Nahdlatul Ulama Purwokerto \\ ${ }^{2}$ Program Studi Teknik Pertanian, Fakultas Pertanian, Universitas Jenderal Soedirman \\ ${ }^{\otimes}$ Komunikasi Penulis, email: syska.kavadya@unupurwokerto.ac.id \\ DOI:http://dx.doi.org/10.23960/jtep-l.v10i3.338-350
}

Naskah ini diterima pada 16 Desember 2020; revisi pada 24 Mei 2021; disetujui untuk dipublikasikan pada 4 Agustus 2021

\begin{abstract}
After harvesting, fruits will change due to physiological, physical, chemical, and microbiological influences, and they are living materials. Therefore, it is necessary to know how to harvest and handle fresh fruits and their storage conditions to handle the fruits after harvesting so that the quality of the products can be maintained. One of the first treatments in the fruit cold chain is evaporative cooling. In order to get an evaporative cooling system that has an even temperature distribution, it is necessary to make a spatial model when designing an evaporative cooling system using CFD (Computational Fluid Dynamics). The objectives of this research are: (1) design of direct flow type evaporative cooling systems and (2) test the performance of direct flow type evaporative coolers. This research method uses design methods, experiments, and computer simulations. The results showed the performance of the evaporative cooler system in the scenario with the roof on, the highest effectiveness value was 1.198, the highest approximation value was 2.832, and the highest range value was 4.589. In the scenario without a roof on the evaporative cooler system, the highest effectiveness value was 1.767, the highest approach value was 2.139, and the highest range value was 4.835. The CFD analysis in the scenario with a roof had the highest temperature value of $25.9^{\circ} \mathrm{C}$ and the lowest temperature of $21.9^{\circ} \mathrm{C}$, while the CFD analysis in the scenario without roof had the highest temperature of $23.7^{\circ} \mathrm{C}$ and the lowest temperature of $20.4^{\circ} \mathrm{C}$.
\end{abstract}

Keywords : CFD, direct flow type, evaporative cooler, quality, fruit

\begin{abstract}
ABSTRAK
Buah-buahan setelah dipanen akan mengalami perubahan akibat pengaruh fisiologis, fisik, kimia, dan mikrobiologis, oleh karena itu masih disebut bahan hidup. Untuk menangani buah-buahan setelah panen perlu diketahui cara-cara pemanenan dan penanganan segar serta kondisi penyimpanannya, sehingga mutu produk dapat dipertahankan. Salah satu penanganan awal dalam rantai dingin buah-buahan yaitu pendingin evaporatif. Guna mendapatkan sistem pendingin evaporatif yang memiliki distribusi suhu yang merata, perlu dibuat model spasial pada waktu merancang sistem pendingin evaporatif menggunakan CFD (Computational Fluid Dynamics). Tujuan penelitian ini yaitu: (1) rancang bangun sistem pendingin evaporatif tipe aliran searah dan (2) uji kinerja pendingin evaporatif tipe aliran searah. Metode penelitian ini menggunakan metode rancangbangun, eksperimen, dan simulasi komputer. Hasil penelitian menunjukkan kinerja sistem pendingin pada skenario dengan atap pada pendingin evaporatif, nilai efektifitas tertinggi sebesar 1,198, nilai hampiran tertinggi sebesar 2,832, dan nilai kisaran tertinggi sebesar 4,589. Pada skenario tanpa atap pada pendingin evaporatif, nilai efektifitas tertinggi sebesar 1,767, nilai hampiran tertinggi sebesar 2,139, dan nilai kisaran tertinggi sebesar 4,835. Analisis CFD pada skenario dengan atap memiliki nilai suhu tertinggi $25,9^{\circ} \mathrm{C}$ dan suhu terendah $21,9^{\circ} \mathrm{C}$, sedangkan analisis CFD pada skenario tanpa atap memiliki suhu tertinggi $23,7^{\circ} \mathrm{C}$ dan suhu terendah $20,4^{\circ} \mathrm{C}$.
\end{abstract}

Kata kunci: buah-buahan, CFD, mutu, pendingin evaporatif, tipe aliran searah 


\section{PENDAHULUAN}

Buah-buahan pada umumnya setelah dipanen jika dibiarkan begitu saja lama-kelamaan akan mengalami perubahan-perubahan akibat pengaruh fisiologis, fisik, kimia, dan mikrobiologis, salah satunya yaitu Nanas Madu (Ananas Comosus L.) (Roda et al., 2019; Hong et al., 2019; Todkar dan Patil, 2019; Banerjee et al., 2019). Buah-buahan setelah dipanen masih melakukan proses respirasi, oleh karena itu masih disebut bahan hidup (Siddiqui, 2018). Karena sifat-sifatnya yang masih hidup, maka untuk menangani buah-buahan setelah dipanen perlu diketahui cara-cara pemanenan dan penanganan segar serta kondisi penyimpanannya, sehingga mutu produk dapat dipertahankan (Elhadi dan Armando, 2018). Kebanyakan petani kita/produsen buah-buahan masih kurang mengetahui pentingnya kegiatan penanganan lepas panen, sehingga hasil panen yang dianggap baik, mengalami kemerosotan mutu (Gardas et al., 2017).

Penanganan rantai dingin di hulu (di lokasi panen) di Indonesia masih sangat diabaikan karena keterbatasan fasilitas dan pola yang berlaku di tingkat petani (Goyal et al., 2018; Gardas et al., 2017). Sementara itu, kehilangan mutu sesaat setelah panen sangat besar karena produk masih mengandung panas lapangan (field heat) yang harus segera dibuang demi mempertahankan mutu produk tersebut (Arora et al., 2007). Penghilangan panas lapangan melalui penurunan suhu beberapa derajat dari suhu lingkungan sangat berpengaruh besar terhadap masa simpan buah-buahan (Yousuf dan Srivastava, 2019). Untuk meningkatkan nilai tambah yang diperoleh petani, maka sistem penyimpanan sementara setelah panen perlu diperkenalkan (Ghio et al., 2000). Penyimpanan sementara berarti penyimpanan dalam jangka waktu beberapa hari sebelum produk dijual ke pedagang pengumpul atau sejenisnya (Gardas et al., 2017; Wills dan Golding, 2015).

Menurut Wills dan Golding (2016), umur simpan buah-buahan dipengaruhi oleh beberapa faktor antara lain mutu buah-buahan, intensitas respirasi, dan kondisi penyimpanan. Respirasi yang tinggi pada umumnya disertai dengan umur simpan yang pendek (Roda et al., 2019). Sebagian besar buah-buahan lebih disukai dikonsumsi dalam keadaan segar. Oleh karena itu, diupayakan berbagai cara untuk mempertahankan kesegaran buah-buahan agar dapat bertahan lama dan bisa dikonsumsi dalam keadaan segar dalam waktu yang lebih lama setelah masa panen. Salah satu caranya adalah dengan menyimpan dalam kamar pendingin (Gaspar et al., 2015; Thompson, 2014).

Sistem penyimpanan sementara buah-buahan bekerja pada suhu rendah, oleh karena itu, diperlukan sistem pendingin yang dapat digunakan pada sistem penyimpanan sementara tersebut (Gaspar et al., 2015; Pearlmutter et al., 2008). Salah satu sistem sistem pendingin yang dapat diterapkan pada lokasi panen adalah sistem pendingin evaporatif (Jain, 2007). Pendingin evaporatif terjadi akibat penguapan air pada permukaan bebas dengan bantuan aliran udara (Pearlmutter et al., 2008). Keunggulan sistem pendingin evaporatif adalah tidak menggunakan energi komersial (yang mahal dan sulit ditemukan di lokasi panen), rendah energi, dan tidak memerlukan biaya investasi yang tinggi karena dapat dilakukan dengan memodifikasi gudang penyimpanan yang telah dimiliki petani, serta tidak merepotkan petani dengan keperluan tingkat keahlian tertentu (Taufiq et al., 2007). Selain itu, menurut Wang (2007), sistem pendingin evaporatif yang ada saat ini memiliki kelemahan, yaitu distribusi suhu yang kurang merata dalam ruang penyimpanan dingin. Distribusi suhu yang tidak merata dapat menyebabkan mutu buah-buahan tidak seragam, bahkan penurunan mutu (Wanphen dan Nagano, 2009).

Berdasarkan hal tersebut, solusi alternatif yang dipandang efektif adalah penerapan sistem pendingin evaporatif pada sistem penyimpanan sementara buah-buahan (Goyal et al., 2018; Taufik et al., 2007). Penyimpanan sementara menggunakan sistem pendingin evaporatif belum banyak dikembangkan di Indonesia. Guna mendapatkan sistem pendingin evaporatif yang memiliki distribusi suhu yang merata, akan dibuat simulasi model spasial (menggunakan finite volume) pada waktu merancang sistem pendingin evaporatif menggunakan CFD (Computational Fluid Dynamics) (Sun, 2019). 


\section{BAHAN DAN METODE}

Bahan yang digunakan untuk penelitian ini adalah bahan baku pembuatan alat meliputi: kipas, rak aluminium, nozzel, selang $1 / 4$ inch, kaca dengan ketebalan $5 \mathrm{~mm}$, sprayer dengan kapasitas $7 \mathrm{l}$, aluminium foil dengan ketebalan $1,3 \times 10^{-3} \mathrm{~mm}$, styrofoam $1,5 \mathrm{~cm}$. Bahan yang digunakan adalah air sebagai media pendingin evaporattif. Alat yang digunakan meliputi: perangkat komputer yang dilengkapi software Fluent 6.1 dan Gambit 2.2.30 untuk analisis CFD, perlengkapan perbengkelan (untuk rancangbangun), termometer, termokopel, hibrid recorder, dan anemometer.

\subsection{Prosedur Penelitian}

Penelitian dilakukan dalam beberapa tahapan antara lain:

1) Rancang bangun Pendingin Evaporatif Peralatan yang digunakan meliputi peralatan disain (perancangan) dan peralatan pabrikasi. Peralatan disain menggunakan seperangkat komputer dengan program menggambar teknik dan peralatan pabrikasi meliputi alat dan mesin yang tersedia di bengkel. Perancangan bertujuan untuk memperoleh suatu prototipe sistem pendingin evaporatif yang optimal, sesuai dengan fungsi dan kegunaannya. Dalam perancangan dilakukan pemilihan komponenkomponen standar dan mudah diperoleh dipasaran. Pendingin evaporatif akan dibuat dengan kondisi seperti pada Gambar 1.
2) Pengukuran Pendingin Evaporatif

(a) Pengukuran tekanan sprayer, debit air yang dialirkan sprayer, dan kecepatan kipas.

(b) Pengukuran suhu lingkungan, kelembaban lingkungan, suhu air masuk, dan suhu air keluar selama 1 jam dengan interval pengukuran 10 menit. Interval 10 menit lebih baik bila dibandngkan penelitian-penelitian pendinginan evaporatif lainnya, yaitu dengan interval 15 menitt (Aziz et al., 2014).

(c) Pengukuran suhu pada sepuluh titik pengukuran mengunakan termometer alkohol selama 1 jam dengan interval pengukuran 10 menit.

(d) Pengukuran kelembaban dengan menggunakan termometer bola basah dan bola kering selama 1 jam dengan interval pengukuran 10 menit.

3) Skenario Pengambilan Data

Skenario digunakan untuk pengambilan data menjadi dua, yaitu: (1) Skenario A (dengan atap pada ruang pendingin evaporatif) dan (2) Skenario B (tanpa atap pada ruang pendingin evaporatif). Variabel yang diukur pada masingmasing skenario yaitu: kecepatan kipas dan kecepatan sprayer. Kecepatan kipas dibagi menjadi tiga, yaitu: $3 \mathrm{~m} / \mathrm{s}$ (K1), 4 m/s (K2), dan $5 \mathrm{~m} / \mathrm{s}$ (K3). Sedangkan kecepatan spayer dilakukan pada bukaan nozel yaitu: dua nozel terbuka penuh $(2 \mathrm{~F})$, dua nozel terbuka setengah

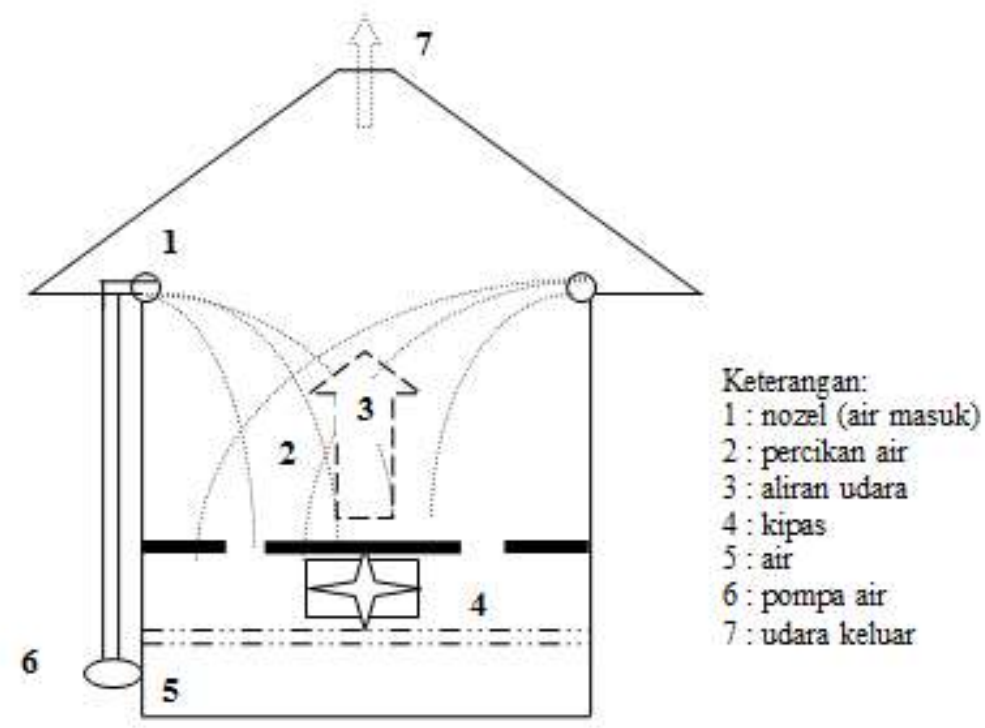

Gambar 1. Skema Ruang Penyimpanan Sementara dengan Pendinginan Evaporatif 
$\left(2 \mathrm{~F}^{1 / 2}\right)$, satu nozel terbuka penuh $(1 \mathrm{~F})$, dan satu nozel terbuka setengah $\left(1 \mathrm{~F}^{1} / 2\right)$. Kombinasi pada tiap skenario disajikan pada Tabel 1 dan Tabel 2 . Pengujian dilakukan tanpa beban pendinginan.

\subsection{Analisis Data}

Analisis sistem pendingin evaporatif dilakukan dengan melakukan beberapa prosedur antara lain:

1. Perhitungan laju pelepasan kalor dari air

2. Perhitungan laju kalor yang diterima udara

3. Kinerja pendingin evaporatif (Taufiq et al., 2007; Wanphen dan Nagano, 2009).

a. Hampiran, menggunakan persamaan berikut:

Hampiran=Suhu udara keluar $-\mathrm{Tbb}(1)$

b. Kisaran, menggunakan persamaan berikut:
Kisaran $=$ Tbk - Suhu udara keluar

c. Efektifitas, menggunakan persamaan berikut:

Efektifitas $=\frac{T b k-\text { Suhu Udara keluar }}{(T b k-T b b)}$

dimana, Tbb adalah suhu bola basah dan Tbk adalah suhu bola kering.

4. Analisis distribusi suhu model pendinginan evaporatif menggunakan teknik CFD. Analisis dengan menggunakan CFD dilakukan dengan menentukan kondisi batas dan memasukkan beberapa variabel kedalam program CFD.

Model dibuat menggunakan pendekatan spasial dengan metode Finite Volume, menggunakan bentuk integral pada persamaan keseimbangan

Tabel 1. Skenario Penelitian A: Dengan Atap pada Ruang Pendingin Evaporatif

\begin{tabular}{|c|c|c|c|c|c|c|}
\hline No. & Kipas & Atap & Rak & Sprayer & Bahan & Jumlah Percobaan \\
\hline A1 & 3 & $\mathrm{~V}$ & $\mathrm{~V}$ & $2 \mathrm{~F}$ & - & 3 \\
\hline $\mathrm{A} 2$ & 3 & V & V & $2 \mathrm{~F}^{1} 1 / 2$ & - & 3 \\
\hline A3 & 2 & V & V & $2 \mathrm{~F}$ & - & 3 \\
\hline A4 & 2 & V & V & $2 \mathrm{~F}^{1} / 2$ & - & 3 \\
\hline A5 & 1 & V & V & $2 \mathrm{~F}$ & - & 3 \\
\hline A6 & 1 & V & V & $2 \mathrm{~F}^{1} / 2$ & - & 3 \\
\hline A7 & 3 & V & V & $1 \mathrm{~F}$ & - & 3 \\
\hline A8 & 3 & V & V & $1 F^{1 / 2}$ & - & 3 \\
\hline A9 & 2 & V & V & $1 \mathrm{~F}$ & - & 3 \\
\hline A10 & 2 & V & V & $1 F^{1 / 2}$ & - & 3 \\
\hline A11 & 1 & V & V & $1 \mathrm{~F}$ & - & 3 \\
\hline A12 & 1 & V & V & $1 \mathrm{~F}^{1 / 2}$ & - & 3 \\
\hline
\end{tabular}

Keterangan: $2 \mathrm{~F}$ = dua nozel terbuka penuh, $2 \mathrm{~F}^{1 / 2}=$ dua nozel terbuka setengah, $1 \mathrm{~F}=$ satu nozel terbuka penuh, $1 \mathrm{~F}^{1 / 2}$ = satu nozel terbuka setengah, $\mathrm{V}=$ tersedia, - = tidak ada

Tabel 2. Skenario Penelitian B: Tanpa Atap pada Ruang Pendingin Evaporatif

\begin{tabular}{ccccccc}
\hline No. & Kipas & Atap & Rak & Sprayer & Bahan & Jumlah Percobaan \\
\hline B1 & 3 & - & $\mathrm{V}$ & $2 \mathrm{~F}$ & - & 3 \\
B2 & 3 & - & $\mathrm{V}$ & $2 \mathrm{~F}^{1 / 2}$ & - & 3 \\
B3 & 2 & - & $\mathrm{V}$ & $2 \mathrm{~F}$ & - & 3 \\
B4 & 2 & - & $\mathrm{V}$ & $2 \mathrm{~F}^{1 / 2}$ & - & 3 \\
B5 & 1 & - & $\mathrm{V}$ & $2 \mathrm{~F}$ & - & 3 \\
B6 & 1 & - & $\mathrm{V}$ & $2 \mathrm{~F}^{1 / 2}$ & - & 3 \\
B7 & 3 & - & $\mathrm{V}$ & $1 \mathrm{~F}$ & - & 3 \\
B8 & 3 & - & $\mathrm{V}$ & $1 \mathrm{~F}^{1 / 2}$ & - & 3 \\
B9 & 2 & - & $\mathrm{V}$ & $1 \mathrm{~F}$ & - & 3 \\
B10 & 2 & - & $\mathrm{V}$ & $1 \mathrm{~F}^{1 / 2}$ & - & 3 \\
B11 & 1 & - & $\mathrm{V}$ & $1 \mathrm{~F}$ & - & 3 \\
B12 & 1 & - & $\mathrm{V}$ & $1 \mathrm{~F}^{1 / 2}$ & - & 3 \\
\hline
\end{tabular}

Keterangan: $2 \mathrm{~F}=$ dua nozel terbuka penuh, $2 \mathrm{~F}^{1} \frac{1}{2}=$ dua nozel terbuka setengah, $1 \mathrm{~F}=$ satu nozel terbuka penuh, $1 \mathrm{~F}^{1 / 2}$ = satu nozel terbuka setengah, $\mathrm{V}=$ tersedia, - = tidak ada 


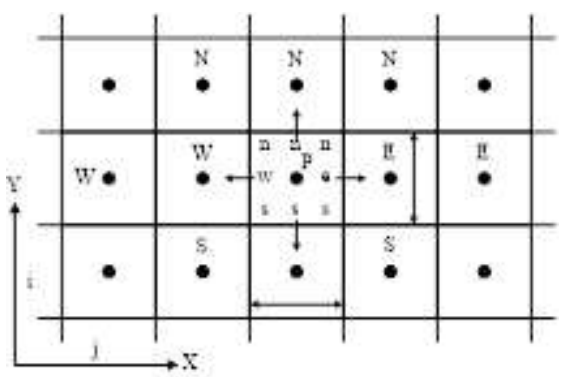

Gambar 2. Penentuan Node pada Koordinat Cartesian 2D
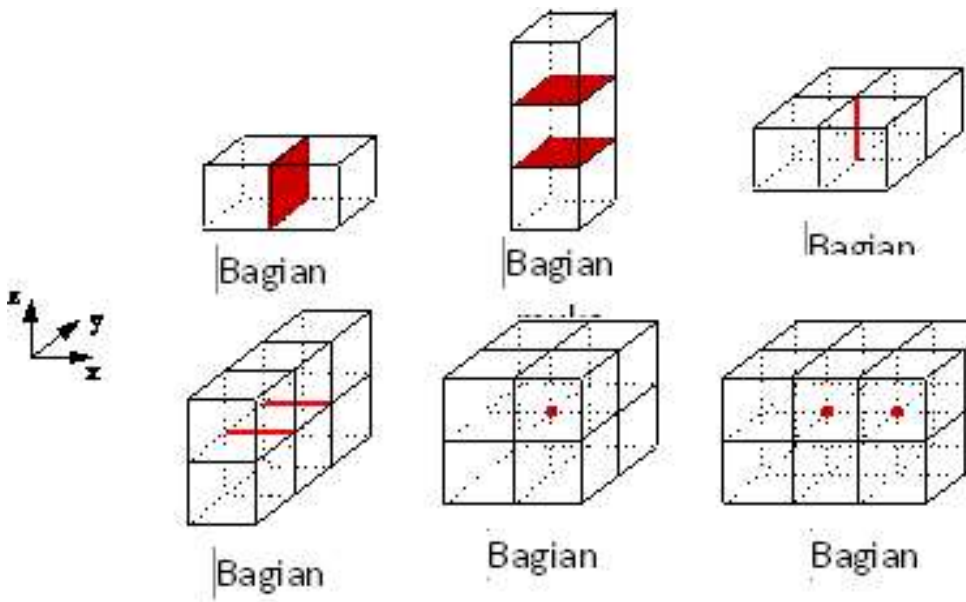

Gambar 3. Penempatan Node Koordinat Cartesian 3D

(Sun, 2019). Model didefinisikan kontrol volume terhadap batas menggunakan beberapa node. Bentuk integral pada persamaan keseimbangan yang digunakan sebagai berikut (Sun, 2019):

$$
\int_{S} f d S=\sum_{i} \int_{S k} f d S
$$

\subsection{Kode CFD}

Sun (2019) menjelaskan bahwa pemecahan simulasi menggunakan software CFD, yaitu: Fluent 6.1 (Fluent inc) dan pembentukan geometri alat menggunakan software Gambit 2.2.30 (Fluent inc). Kode CFD mengandung tiga elemen utama, yaitu: pre-processor, solver, dan post-processor.

\section{HASIL DAN PEMBAHASAN}

\subsection{Rancangbangun dan Analisis Pendingin Evaporatif}

Pengembangan dilakukan pada sumber fluida yang dievaporasikan dan jenis exhaust. Pada penelitian ini dikembangkan pendingin evaporatif tipe evaporasi langsung aliran searah (Gambar 4). Butiran fluida sudah berbentuk kabut sehingga akan meningkatkan kinerja alat.
Spesifikasi rancangan pendingin evaporatif (Gambar 5) dibuat sebagai berikut; komponen utama dari sistem pendingin evaporatif adalah ruang pendingin. Ruang pendingin terdiri atas dua buah volume yang digabungkan. Volume pertama berbentuk kubus dengan dimensi $\mathrm{p} \times \mathrm{l} \times$ t adalah $100 \mathrm{~cm} \times 100 \mathrm{~cm} \times 100 \mathrm{~cm}$. Volume kedua berbentuk piramida dengan dimensi $\mathrm{p} \times \mathrm{l} \times \mathrm{t}$ adalah $120 \mathrm{~cm} \times 120 \mathrm{~cm} \times 45 \mathrm{~cm}$. Pada bagian bawah volume kubus terdapat lubang dengan diameter $30 \mathrm{~cm}$ yang berfungsi sebagai lubang pengeluaran air dan dudukan kipas. Selain itu, pada bagian atas sisi kiri dan kanan terdapat lubang dengan diameter $2 \mathrm{~cm}$ yang berfungsi sebagai dudukan nozel. Bagian atas volume piramida memiliki bidang dengan luas $12 \mathrm{~cm} \times$ $12 \mathrm{~cm}$ dan terdapat lubang dengan diameter 4 $\mathrm{cm}$ pada bagian tengah. Lubang ini berfungsi untuk mengeluarkan udara. Dinding ruang pendingin terbuat dari tiga lapisan bahan yang berbeda yaitu plat aluminium, stryrofoam, dan aluminium foil. Plat aluminium memiliki ketebalan sebesar $0,05 \mathrm{~cm}$, stryrofoam dengan ketebalan $1,5 \mathrm{~cm}$, dan aluminium foil dengan ketebalan $1,3 \times 10^{-3} \mathrm{~mm}$. Komponen pelengkap dari sistem pendingin evaporatif adalah sprayer, nozel, rak bahan, kipas, dan selang. 


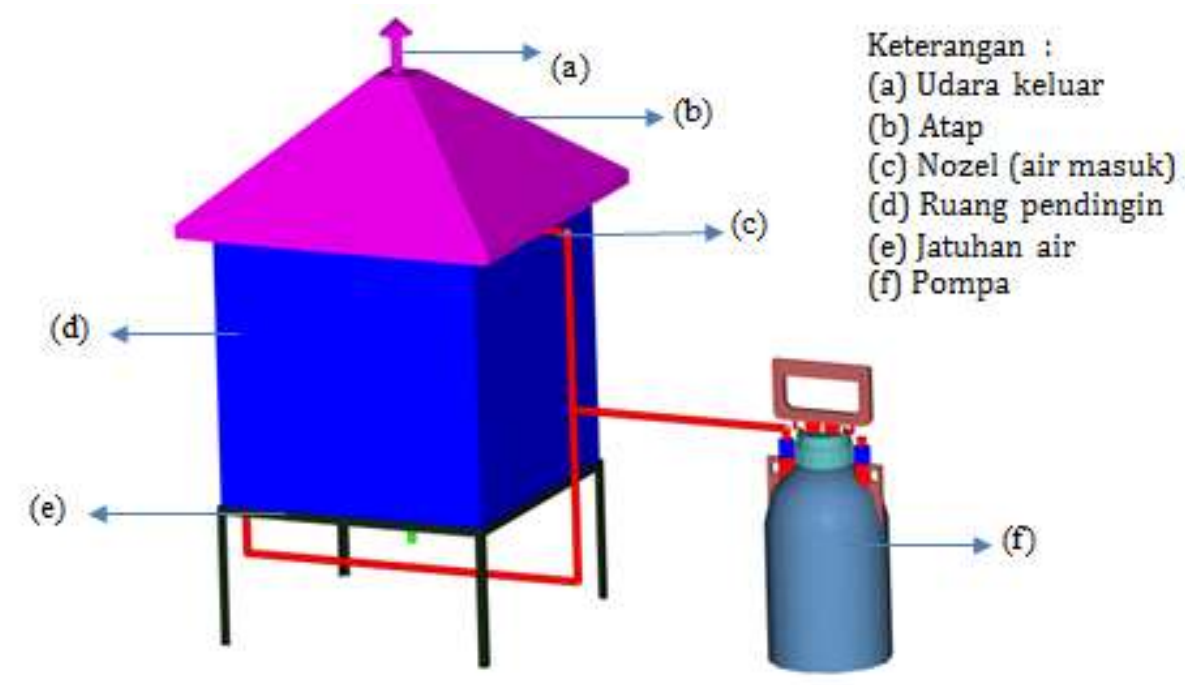

Gambar 4. Pendingin Evaporatif yang Dikembangkan

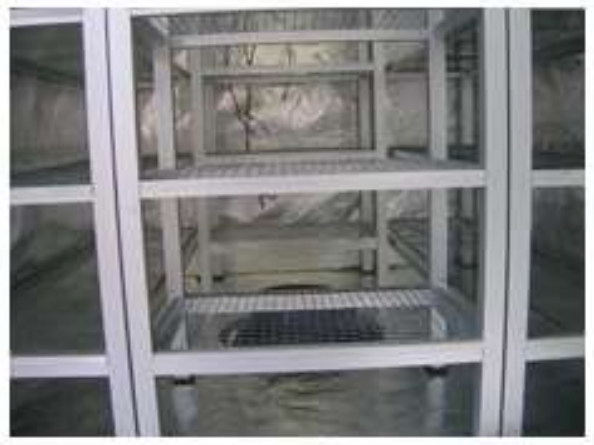

Rak penyimpan produk

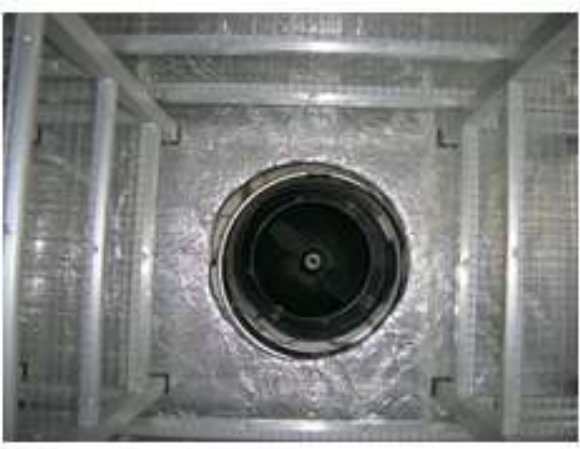

Humidifier dari atas

Gambar 5. Teknologi Pendingin Evaporatif yang Dikembangkan Tipe Evaporasi Langsung Aliran Searah

\subsection{Model CFD}

Analisis suhu yang dilakukan dengan menggunakan CFD didahului dengan pembuatan geometri dan meshing. Pembuatan geometri dan meshing ini bertujuan untuk membentuk bangun yang akan dianalisis. Meshing yang digunakan dalam analisis ini berupa meshing tipe tgrid dengan jenis elemen tet/hybrid. Meshing ini dapat menyesuaikan bentuk elemennya untuk setiap bidang. Gambar 6 merupakan bangun dan meshing yang digunakan.

Analisis pada skenario penelitian memberikan nilai suhu tertinggi sebesar $25,9^{\circ} \mathrm{C}$ dan suhu terendah sebesar $21,9^{\circ} \mathrm{C}$. Analisis pada skenario penelitian adalah A2. Pada hasil analisis A2 suhu yang berdistribusi pada sistem pendingin evaporatif memiliki suhu sebesar $22,3^{\circ} \mathrm{C}$. Distribusi suhu pada skenario penelitian A2 dapat dili hat pada Gambar 7.
Suhu pada bagian dalam bangun terlihat hampir merata secara keseluruhan, pada bagian dinding sebelah kanan terlihat suhu yang sedikit berbeda yaitu pada bagian air masuk. Pada bagian lubang air masuk terlihat sedikit berwarna merah akan tetapi kisaran suhu pada bagian ini berkisar $22,3^{\circ} \mathrm{C}$. Bagian tengah bangun memiliki suhu yang lebih rendah hal ini terlihat dengan warna bagian tengah sedikit gelap. Suhu pada bagian kipas terlihat rendah dengan warna biru tua. Walaupun terlihat perbedaan warna antara bagian-bagian bangun, akan tetapi kisaran suhu tetap berkisar antara $22,3^{\circ} \mathrm{C}$. Hal ini disebabkan karena analisis hanya menggunakan satu desimal, sehingga perbedaan suhu yang diperoleh tidak terlihat secara signifikan.

Tabel 3 menunjukkan hasil perhitungan laju kalor yang diterima udara, laju aliran udara, efektifitas, hampiran, dan kisaran untuk 
pengukuran skenario A. Terlihat bahwa besarnya laju kalor yang tertinggi diterima udara terjadi pada A7 dimana menggunakan kipas dengan kecepatan $5,12 \mathrm{~m} / \mathrm{s}$ dan satu nozel yang terbuka penuh, nilai sebesar 0,52 kJ/s. Sedangkan nilai laju kalor terrendah pada kodisi A4 dimana digunakan kecepatan kipas 4,12 m/s dan menggunakan dua nozel yang dibuka setengah penuh dengan nilai sebesar $0,24 \mathrm{~kJ} / \mathrm{s}$. Nilai laju aliran udara tertinggi terjadi pada kondisi A7 dengan nilai sebesar $2,28 \times 10^{-4} \mathrm{~kg} / \mathrm{s}$ dan nilai laju aliran udara terrendah terjadi pada A4 dengan nilai sebesar $1,06 \times 10^{-4} \mathrm{~kg} / \mathrm{s}$. Nilai efektifitas tertinggi terjadi pada kondisi A9 dimana digunakan kecepatan kipas 4,12 m/s dengan satu nozel yang terbuka penuh, nilai sebesar 1,20. Sedangkan niali effektifitas terrendah sebesar 0,30 yaitu pada kondisi A11 dengan menggunakan kecepatan kipas $3,20 \mathrm{~m} / \mathrm{s}$ dan satu nozel terbuka penuh. Nilai hampiran tertinggi diperoleh pada kondisi A12 dimana mengunakan kecepatan kipas 3,20 m/s dan satu nozel yang terbuka setengah dengan nilai sebesar 1,83 dan hampiran terrendah dengan nilai sebesar 0,69 pada kondisi A7. Nilai kisaran tertinggi terjadi pada kondisi $\mathrm{A} 9$, dengan nilai sebesar 4,34 dan nilai terrendah pada kondisi A11 dengan nilai sebesar 0,65.

Secara teoritis, suhu minimun yang dapat dicapai dengan sistem pendinginan evaporatif adalah suhu bola basah udara lingkungan, sehingga semakin kecil hampiran maka semakin baik kinerja alat. Skenario A memberikan nilai hampiran terkecil pada kondisi A5 yaitu kecepatan kipas rendah dengan dua nozel terbuka penuh, nilai sebesar 0,16.

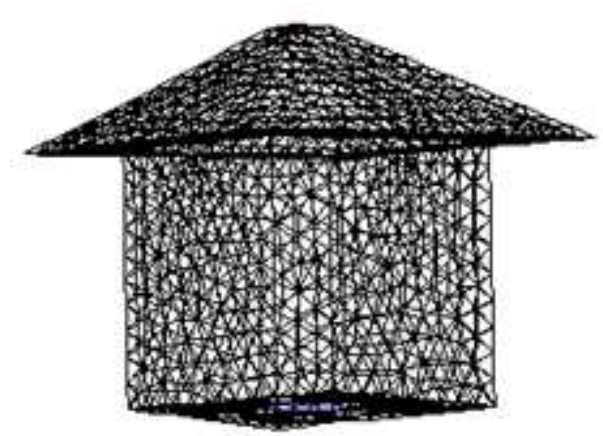

Gambar 6. Bangun dan Meshing pada Penelitian
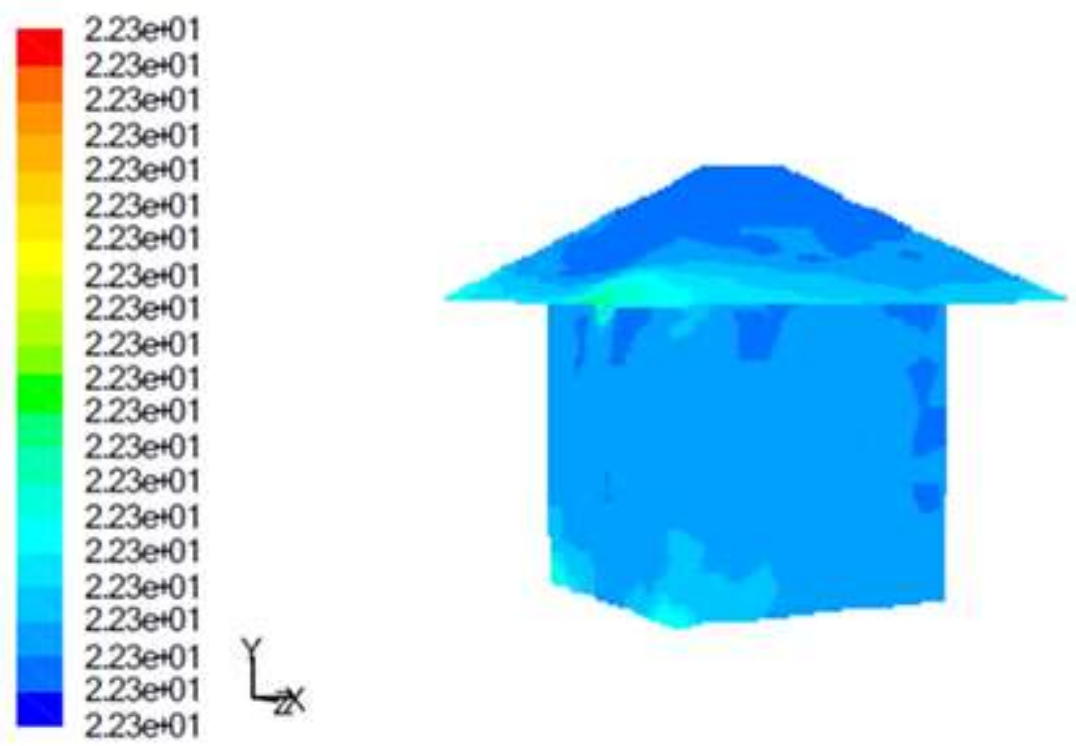

Cortours of Tota Temperatue(c)

FUENT6.2 (3d, segregaed, lam)

Gambar 7. Distribusi Suhu pada CFD 


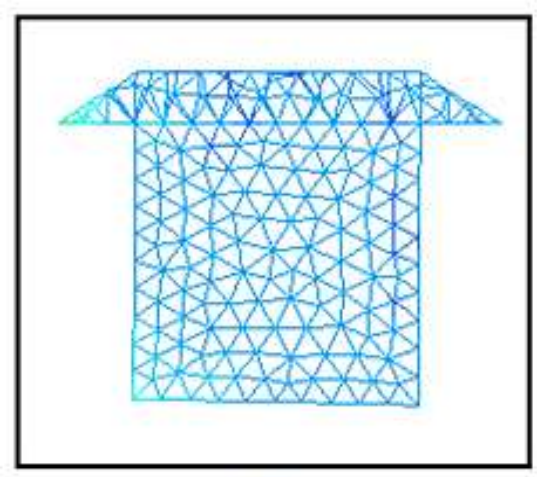

(a)

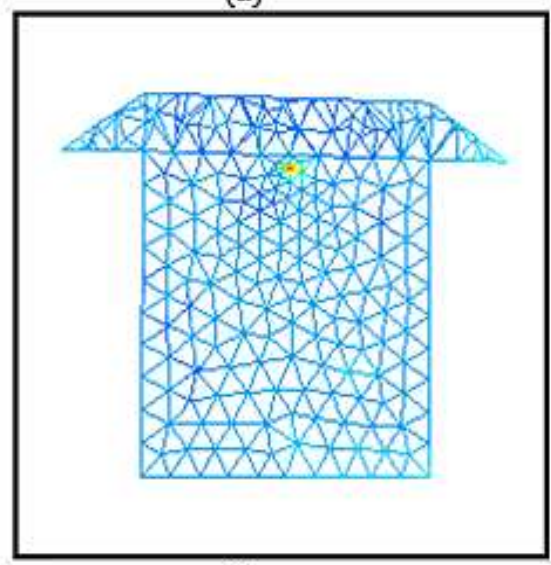

(c)

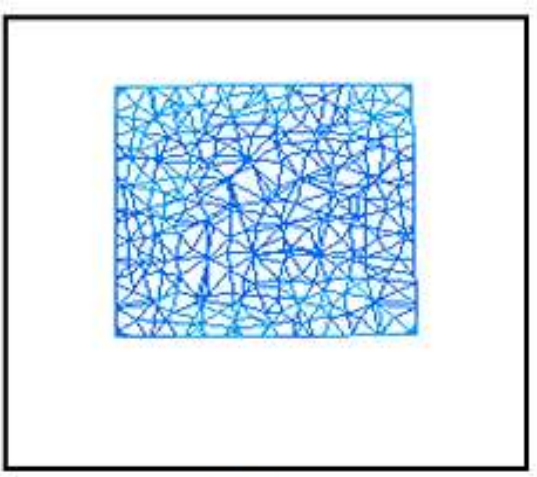

(b)

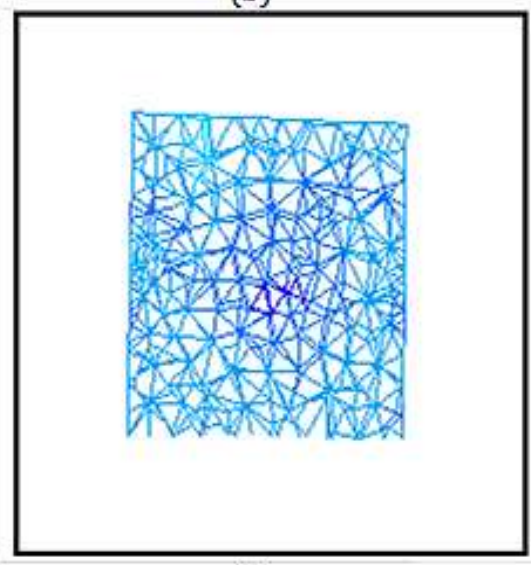

(d)

Gambar 8. Distribusi Suhu CFD pada Beberapa Bagian: (a) Dalam Bangun, (b) Tengah Bangun, (c) Dinding Air Masuk, dan (d) Kipas

Tabel 3. Hasil Perhitungan Skenario A Laju Kalor yang Diterima, Laju Aliran Udara, Efektifitas, Hampiran, dan Kisaran

\begin{tabular}{cccccc}
\hline Kode & dqa=dqu (kJ/s) & $\mathbf{G}(\mathbf{k g} / \mathbf{s})$ & Efektifitas & Hampiran & Kisaran \\
\hline A1 & 0,34 & $1,52 \mathrm{E}-04$ & 0,49 & 0,95 & 0,91 \\
A2 & 0,33 & $1,47 \mathrm{E}-04$ & 0,50 & 1,15 & 1,13 \\
A3 & 0,41 & $1,83 \mathrm{E}-04$ & 1,02 & 0,00 & 3,11 \\
A4 & 0,24 & $1,06 \mathrm{E}-04$ & 0,37 & 1,43 & 0,83 \\
A5 & 0,37 & $1,65 \mathrm{E}-04$ & 0,95 & 0,16 & 2,78 \\
A6 & 0,36 & $1,58 \mathrm{E}-04$ & 0,43 & 1,73 & 1,29 \\
A7 & 0,52 & $2,28 \mathrm{E}-04$ & 0,81 & 0,69 & 2,87 \\
A8 & 0,46 & $2,04 \mathrm{E}-04$ & 0,48 & 1,71 & 1,62 \\
A9 & 0,51 & $2,27 \mathrm{E}-04$ & 1,20 & 0,00 & 4,34 \\
A10 & 0,45 & $1,98 \mathrm{E}-04$ & 0,74 & 0,89 & 2,43 \\
A11 & 0,42 & $1,86 \mathrm{E}-04$ & 0,30 & 1,48 & 0,65 \\
A12 & 0,45 & $2,00 \mathrm{E}-04$ & 0,34 & 1,83 & 0,94 \\
\hline Maksimum & $\mathbf{0 , 5 2}$ & $\mathbf{2 , 2 8 E - 0 4}$ & $\mathbf{1 , 2 0}$ & $\mathbf{1 , 8 3}$ & $\mathbf{4 , 3 4}$ \\
\hline Minimum & $\mathbf{0 , 2 4}$ & $\mathbf{1 , 0 6 E - 0 4}$ & $\mathbf{0 , 3 0}$ & $\mathbf{0 , 1 6}$ & $\mathbf{0 , 6 5}$ \\
\hline Rerata & $\mathbf{0 , 4 1}$ & $\mathbf{1 , 7 9 E - 0 4}$ & $\mathbf{0 , 6 4}$ & $\mathbf{1 , 0 1}$ & $\mathbf{1 , 9 1}$ \\
\hline
\end{tabular}

Keterangan: $\mathrm{G}$ = laju aliran udara, dqa = laju kalor yang diterima air, dqu = laju kalor yang diterima udara

Tabel 4 menunjukkan hasil perhitungan laju kalor yang diterima udara, laju aliran udara, efektifitas, hampiran, dan kisaran untuk pengukuran skenario B. Terlihat bahwa besarnya laju kalor yang tertinggi diterima udara terjadi pada B9 dimana digunakan kecepatan kipas 3,20 m/s dengan satu nozel yang terbuka penuh, nilai sebesar $0,47 \mathrm{~kJ} / \mathrm{s}$. Sedangkan nilai 
laju kalor terrendah pada kondisi B1 dengan menggunakan kecepatan kipas 5,12 m/s dan menggunakan dua nozel terbuka penuh dengan nilai sebesar $0,32 \mathrm{~kJ} / \mathrm{s}$. Nilai laju aliran udara tertinggi terjadi B9 dengan nilai sebesar $2,09 \times 10^{-4} \mathrm{~kg} / \mathrm{s}$ dan nilai terrendah sebesar $1,44 \times 10^{-4} \mathrm{~kg} / \mathrm{s}$ pada kondisi B1. Nilai efektifitas tertinggi terjadi pada kondisi B3 dimana digunakan kecepatan kipas 4,12 m/s dengan dua nozel yang terbuka penuh, nilai sebesar 1,77. Sedangkan nilai efektifitas terrendah sebesar 0,84 pada kondisi B11 dengan menggunakan kecepatan kipas 3,20 m/s dan menggunakan satu nozel terbuka penuh. Nilai hampiran tertinggi diperoleh pada kondisi B12 dimana menggunakan kecepatan kipas 3,20 m/s dengan satu nozel yang terbuka setengah, nilai sebesar 20,24 . Nilai hampiran terkecil diperoleh pada kondisi B7 dimana digunakan kecepatan kipas $5,12 \mathrm{~m} / \mathrm{s}$ dengan satu nozel terbuka penuh, nilai sebesar 1,43. Nilai kisaran tertinggi terjadi pada kondisi B5 dimana digunakan kecepatan kipas $3,20 \mathrm{~m} / \mathrm{s}$ dengan dua nozel yang terbuka penuh, dengan nilai sebesar 4,84 dan nilai terrendah sebesar 2,01 pada kondisi B3.

Keadaan suhu dalam ruang pendingin berfluktuasi dengan nilai terendah sebesar $18,05^{\circ} \mathrm{C}$ dan suhu tertinggi sebesar $25,81^{\circ} \mathrm{C}$ untuk skenario $\mathrm{A}$. skenario B nilai terendah sebesar $16,63^{\circ} \mathrm{C}$ dan

Tabel 4. Hasil Perhitungan Skenario B Laju Kalor yang Diterima, Laju Aliran Udara, Efektifitas, Hampiran, dan Kisaran

\begin{tabular}{cccccc}
\hline Kode & dqa $=$ dqu (kJ/s) & $\mathbf{G ~} \mathbf{( k g} / \mathbf{s})$ & Efektifitas & Hampiran & Kisaran \\
\hline B1 & 0,32 & $1,44 \mathrm{E}-04$ & 1,51 & 1,81 & 2,10 \\
B2 & 0,38 & $1,68 \mathrm{E}-04$ & 1,36 & 1,59 & 3,67 \\
B3 & 0,39 & $1,70 \mathrm{E}-04$ & 1,77 & 1,71 & 2,01 \\
B4 & 0,40 & $1,79 \mathrm{E}-04$ & 1,29 & 1,89 & 2,98 \\
B5 & 0,37 & $1,65 \mathrm{E}-04$ & 1,27 & 1,63 & 4,84 \\
B6 & 0,37 & $1,65 \mathrm{E}-04$ & 1,43 & 1,86 & 3,19 \\
B7 & 0,45 & $1,99 \mathrm{E}-04$ & 1,49 & 1,43 & 3,38 \\
B8 & 0,42 & $1,85 \mathrm{E}-04$ & 1,22 & 1,93 & 3,21 \\
B9 & 0,47 & $2,09 \mathrm{E}-04$ & 1,58 & 1,65 & 2,66 \\
B10 & 0,41 & $1,80 \mathrm{E}-04$ & 1,39 & 1,90 & 2,34 \\
B11 & 0,44 & $1,96 \mathrm{E}-04$ & 0,85 & 1,87 & 2,08 \\
B12 & 0,39 & $1,77 \mathrm{E}-04$ & 1,35 & 2,02 & 2,21 \\
\hline Maksimum & $\mathbf{0 , 4 7}$ & $\mathbf{2 , 0 9 E - 0 4}$ & $\mathbf{1 , 7 7}$ & $\mathbf{2 , 0 2}$ & $\mathbf{4 , 8 4}$ \\
\hline Minimum & $\mathbf{0 , 3 2}$ & $\mathbf{1 , 4 4 E - 0 4}$ & $\mathbf{0 , 8 5}$ & $\mathbf{1 , 4 3}$ & $\mathbf{2 , 0 1}$ \\
\hline Rerata & $\mathbf{0 , 4 0}$ & $\mathbf{1 , 7 8 E - 0 4}$ & $\mathbf{1 , 3 8}$ & $\mathbf{1 , 7 8}$ & $\mathbf{2 , 8 9}$ \\
\hline
\end{tabular}

Keterangan: $\mathrm{G}=$ laju aliran udara, dqa = laju kalor yang diterima air, dqu = laju kalor yang diterima udara

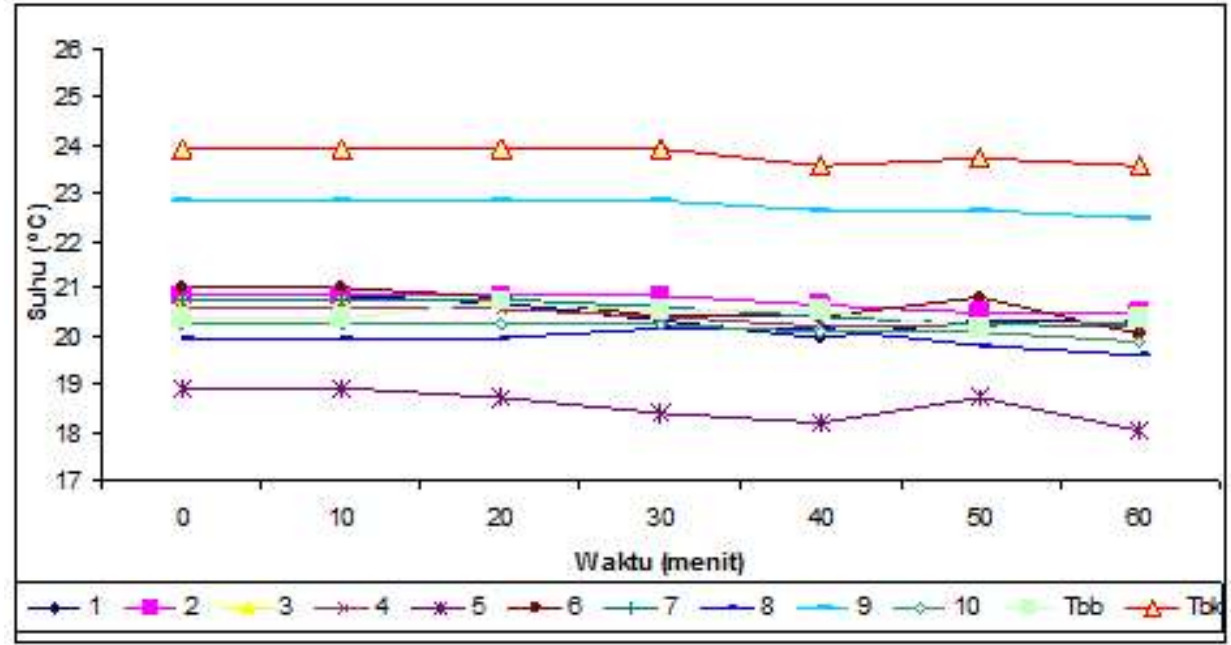

Gambar 9. Pengukuran pada Skenario A 
suhu tertinggi sebesar $23,94^{\circ} \mathrm{C}$. Fluktuasi suhu yang besar terjadi pada titik pengukuran 5 dan titik pengukuran 9 untuk skenario A maupun skenario B. Terjadi penurunan suhu pada titik pengukuran 5 yang sangat besar, sedangkan pada titik pengukuran 9 terjadi peningkatan suhu. Penurunan dan peningkatan suhu pada pengukuran skenario A dapat ditunjukkan pada Gambar 9.

Suhu pada setiap titik pengukuran tidak merata, akan tetapi perbedaan yang terjadi tidak terlalu besar. Pada titik pengukuran 5 terjadi penurunan suhu yang sangat besar di setiap interval waktu pengukuran. Pada titik pengukuran 9 terjadi peningkatan suhu yang sangat besar. Penurunan dan peningkatan suhu pada pengukuran skenario B dapat ditunjukkan pada Gambar 10.
Suhu yang dicapai pada skenario B lebih rendah dibandingkan dengan suhu pada skenario A. Pada skenario A tidak digunakan penutup alat sehingga udara dapat bersirkulasi dengan udara luar. Pada skenario B tidak terjadi penumpukan udara panas yang sulit untuk keluar di dalam ruang sistem pendingin evaporatif.

\subsection{Analisis Data}

Validasi dilakukan untuk mengetahui keakuratan data yang diperoleh dari pengukuran dan perhitungan. Validasi data yang dilakukan pada penelitian ini berupa nilai standar deviasi dan galat Standar deviasi merupakan simpangan baku dari suatu data. Galat suatu bilangan adalah selisih antara suatu nilai yang diketahui dengan suatu pendekatan pada nilai sebenarnya (Nicolai et al., 2001). Nilai standar deviasi dan galat untuk

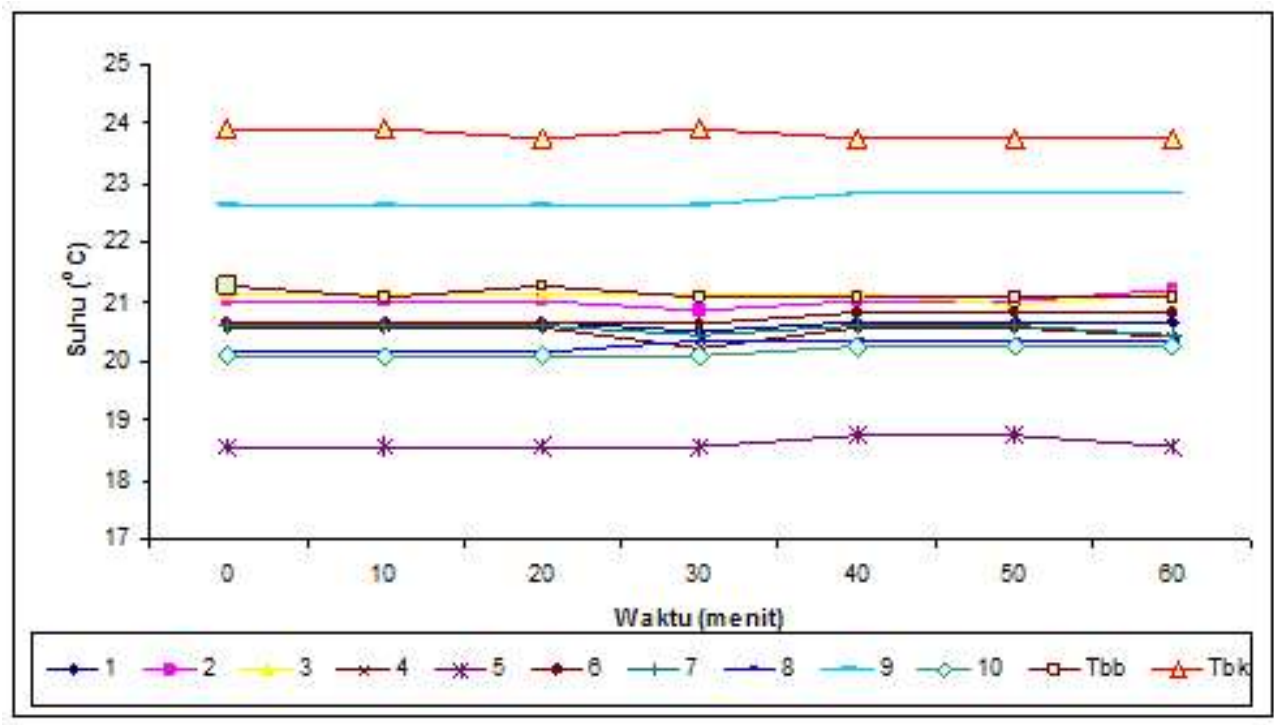

Gambar 10. Pengukuran pada Skenario B

Tabel 5. Nilai Standar Deviasi dan Galat Untuk Skenario Pengukuran A

\begin{tabular}{cccc}
\hline No. & Kode & Standar Deviasi $\left({ }^{\mathbf{0}} \mathbf{C}\right)$ & Galat (\%) \\
\hline 1. & A1 & 1,00 & 7,38 \\
2. & A2 & 1,00 & 7,86 \\
3. & A3 & 2,49 & 21,85 \\
4. & A4 & 1,56 & 14,07 \\
5. & A5 & 1,12 & 8,10 \\
6. & A6 & 1,27 & 9,84 \\
7. & A7 & 1,59 & 12,35 \\
8. & A8 & 1,69 & 15,27 \\
9. & A9 & 1,29 & 9,53 \\
10. & A10 & 1,41 & 12,49 \\
11. & A11 & 0,94 & 6,54 \\
12. & A12 & 1,31 & 10,97 \\
\hline
\end{tabular}




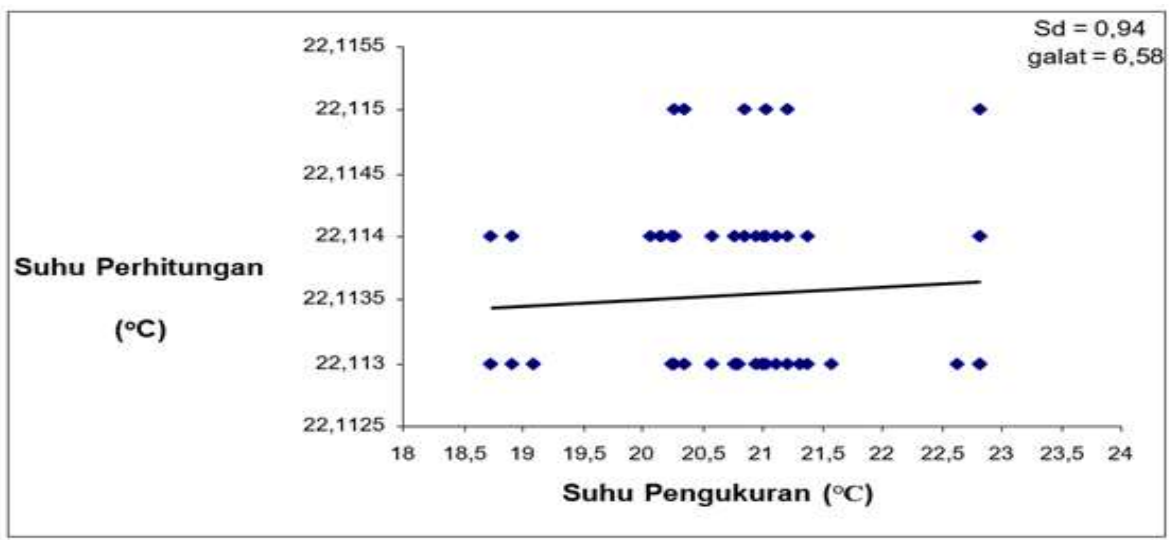

Gambar 11. Standar Deviasi dan Galat Untuk Skenario Penelitian A11

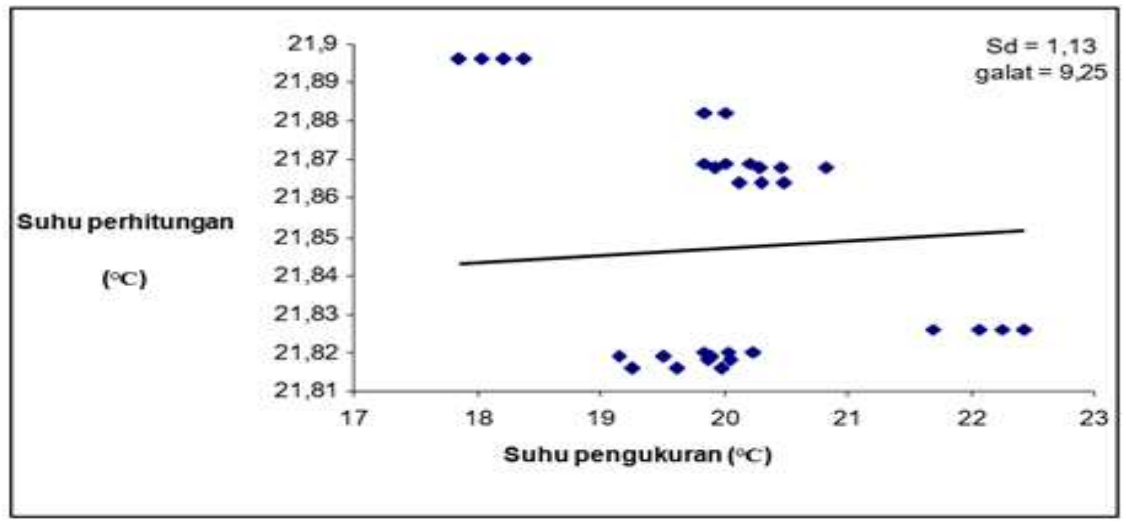

Gambar 12. Standar Deviasi dan Galat Untuk Skenario Penelitian B11

Tabel 6. Nilai Standar Deviasi dan Galat untuk Skenario Pengukuran B

\begin{tabular}{cccc}
\hline No. & Kode & Standar Deviasi $\left(\mathbf{~}^{\mathbf{C}} \mathbf{)}\right.$ & Galat $(\%)$ \\
\hline 1. & B1 & 1,06 & 5,59 \\
2. & B2 & 1,71 & 15,37 \\
3. & B3 & 0,94 & 7,27 \\
4. & B & 1,55 & 13,60 \\
5. & B5 & 3,40 & 22,03 \\
6. & B6 & 3,18 & 32,18 \\
7. & B7 & 1,56 & 13,65 \\
8. & B8 & 1,48 & 13,66 \\
9. & B9 & 1,40 & 10,94 \\
10. & B10 & 1,14 & 9,25 \\
11. & B11 & 1,13 & 9,25 \\
12. & B12 & 1,12 & 9,56 \\
\hline
\end{tabular}

Skenario penelitian B adalah B11. Grafik dan nilai validasi untuk skenario penelitian B11

skenario A tersaji pada Tabel 5. Nilai standar deviasi tertinggi sebesar $2,49^{\circ} \mathrm{C}$ dan terrendah sebesar $0,94^{\circ} \mathrm{C}$. Nilai galat tertinggi sebesar $21,85 \%$ dan terrendah sebesar $6,54 \%$. Nilai validasi skenario penelitian A adalah A11. Standar deviasi yang diperoleh sebesar $0,94^{\circ} \mathrm{C}$ dan galat sebesar $6,58 \%$. Grafik untuk skenario penelitian
A11 disajikan pada Gambar 11. Nilai deviasi dan galat untuk skenario pengukuran B tersaji pada Tabel 6. Nilai standar deviasi tertinggi untuk skenario penelitian $\mathrm{B}$ adalah $3,40^{\circ} \mathrm{C}$ dan terendah $0,94^{\circ} \mathrm{C}$. Nilai galat tertinggi sebesar $32,18 \%$ dan terrendah sebesar 5,59\%. 


\section{KESIMPULAN}

Kinerja sistem pendingin pada skenario A (Dengan atap pada pendingin evaporatif), nilai efektifitas tertinggi sebesar 1,198, nilai hampiran tertinggi sebesar 2,832, dan nilai kisaran tertinggi sebesar 4,589. Pada skenario B (Tanpa atap pada pendingin evaporatif), nilai efektifitas tertinggi sebesar 1,767, nilai hampiran tertinggi sebesar 2,139, dan nilai kisaran tertinggi sebesar 4,835. Analisis CFD pada skenario penelitian A memiliki nilai suhu tertinggi $25,9^{\circ} \mathrm{C}$ dan suhu terrendah $21,9^{\circ} \mathrm{C}$, sedangkan analisis CFD pada skenario penelitian $\mathrm{B}$ memiliki suhu tertinggi $23,7^{\circ} \mathrm{C}$ dan suhu terrendah $20,4^{\circ} \mathrm{C}$.

\section{DAFTAR PUSTAKA}

Arora, S., Gesthuisen, R., dan Engell, S. 2007. Model based operation of emulsion polymerization reactors with evaporative cooling: Application to vinyl acetate homopolymerization. Computers and Chemical Engineering, 31(5-6): 552-564.

Aziz, A., Fauzi, A., dan Irfan, A. 2014. Penerapan Pendingin Evaporatif untuk Kenyamanan Termal. SNTI IV-2014 Universitas Trisakti, ISSN: 2355-925X: 145-1- 145-6. Universitas Trisakti, Jakarta.

Banerjee, S., Ranganathan, V., Patti, A., dan Arora, A. 2019. Valorisation of pineapple wastes for food and therapeutic applications. Trends in Food Science dan Technology, 82(1): 60-70. https://doi.org/10.1016/ j.tifs.2018.09.024

Elhadi, M. Y. dan Armando, C. L. 2018. Postharvest Physiology and Biochemistry of Fruits and Vegetables. Woodhead Publishing. USA.

Gardas, B. B., Raut, R. D., dan Narkhede, B. 2017. Modeling causal factors of post-harvesting losses in vegetable and fruit supply chain: An Indian perspective. Renewable and Sustainable Energy Reviews, 80(1): 13551371.

Gaspar, P. D., Gaspar, P. D., dan Silva, P. D. 2015. Handbook of Research on Advances and
Applications in Refrigeration Systems and Technologies. Engineering Science Reference. USA.

Ghio, S., Barresi, A. A., dan Rovero, G. 2000. A Comparison of Evaporative and Conventional Freezing Prior to FreezeDrying of Fruits and Vegetables. Food and Bioproducts Processing, 78(4): 187-192.

Goyal, M. R., Kaneria, M. J., dan Meghwal, M. 2018. Food Technology: Applied Research and Production Techniques. Apple Academic Press Inc. USA.

Hong, K., Xian, J., Jia, Z., Hou, X., dan Zhang, L. 2019. Genome-wide identification of Dof transcription factors possibly associated with internal browning of postharvest pineapple fruits. Scientia Horticulturae, 251(1): 80-87. https://doi.org/10.1016/ j.scienta.2019.03.007

Jain, D. 2007. Development and testing of twostage evaporative cooler. Building and Environment, 42(7): 2549-2554. https:/ /doi.org/10.1016/j.buildenv.2006.07.034

Nicolai, B. M., Verboven, P., dan Scheerlinck, N. 2001. Modellling and Simulation of Thermal Process. CRC Press. New York. USA.

Pearlmutter, D., Evyatar E., dan Yair E. 2008. A multi-stage down-draft evaporative cool tower for semi-enclosed spaces: Experiments with a water spraying system. Solar Energy, 82(5): 430-440.

Roda, A., Lucini, L., Torchio, F., Dordoni, R., Faveri, D. M., dan Lambri, M. 2019. Metabolite profiling and volatiles of pineapple wine and vinegar obtained from pineapple waste. Food Chemistry, 229(1): 734-742.

Siddiqui, M. W. 2018. Preharvest Modulation of Postharvest Fruit and Vegetable Quality. Academic Press. USA.

Sun, D. W. 2019. Computational Fluid Dynamics in Food Processing. CRC Press. New York. USA. 
Taufiq, B. N., Masjuki, H. H., Mahlia, T. M. I., Amalina, M. A., Faizul, M. S., dan Saidur, R. 2007. Exergy analysis of evaporative cooling for reducing energy use in a Malaysian building. Desalination, 209(13): 238-243. https://doi.org/10.1016/ j.desal.2007.04.033

Thompson, K. 2014. Fruit and Vegetables: Harvesting, Handling and Storage. WileyBlackwell. New York. USA.

Todkar, S. S. dan Patil, S.A. 2019. Review on mechanical properties evaluation of pineapple leaf fibre (PALF) reinforced polymer composites. Composites Part B: Engineering, 174(1): 106927.

Wang, L. dan Sun, D. W. 2001. Rapid cooling of porous and moisture foods by using vacuum cooling technology. Trends in Food Science dan Technology, 12(5-6): 174-184.
Wanphen, S. dan Nagano, K. 2009. Experimental study of the performance of porous materials to moderate the roof surface temperature by its evaporative cooling effect. Building and Environment, 44(2): 338-351.

Wills, R. dan Golding J. 2016. Postharvest: An Introduction to the Physiology and Handling of Fruit and Vegetables. CABI. New York. USA.

Wills, R.B.H. dan Golding, J.B. 2015. Advances in Postharvest Fruit and Vegetable Technology. CRC Press. New York. USA.

Yousuf, B. dan Srivastava, A.K. 2019. Impact of honey treatments and soy protein isolatebased coating on fresh-cut pineapple during storage at $4^{\circ} \mathrm{C}$. Food Packaging and Shelf Life, (21)1: 100361. https://doi.org/ 10.1016/j.fpsl.2019.100361 